\title{
TOURISM AND ENVIRONMENT: TOWARD PROMOTING SUSTAINABLE DEVELOPMENT OF TOURISM: A HUMAN RIGHTS PERSPECTIVE ${ }^{1}$
}

\author{
Ni Ketut Supasti Dharmawan ${ }^{2}$
}

\begin{abstract}
Tourism activities in era globalization bring positive and negative impacts especially for the host countries destination. To minimize the negative impacts it is very important to always promote the sustainable development of tourism including from a human rights perspective. This paper will discuss concerning who have responsibility to promote a human rights related with sustainable development of tourism.

To explore the topic in this article, Author will study both international human rights instruments and environmental convention as well as the soft law regarding the tourism sector such as the UN WTO Global Code Of Ethics. The Law No. 10 Year 2009 concerning Indonesia Tourism Law is also part of legal material studied in this paper. There are national, international legal instruments of the human rights as well as UNWTO Global Codes of Ethics which can be utilized to promote sustainable tourism through human rights perspective. It is considered that all stakeholders have responsibility to promote sustainable development of tourism
\end{abstract}

Keywords: national and international instruments, tourism, sustainable development

\section{Introduction}

A discourse of the environment is not always associated with tourism, but there is no doubt that the discussion of tourism is always associated with the environment. In addition, many studies have shown that the growth and development of the tourism industry bring both positive and negative impacts for the destinations. The positive impacts of these activities are increased tax revenues, open job opportunities for communities and for the construction of adequate infrastructure, etc. On the other hands, the negative impacts of it are environmental damage both environment in terms of natural ecosystems such as air pollution, exploitation of water resources, destruction of coral reef as well as environmental damage in the social dimensions such as the behavior of tourists which are sometimes inappropriate with the local cultures. Therefore, it

${ }^{1}$ The paper presented in International Seminar on Environmental, Health and Safety risks in a Globalizing World, Bali-Indonesia 27-28 June 2011, organized by METRO, MUNDO, Maastricht University the Netherlands and Faculty of Law Udayana University Bali.

${ }^{2}$ Ni KetutSupasti Dharmawan is a lecturer of Business Law (IPR), Faculty of Law University of Udayana Denpasar-Indonesia. Obtained Bachelor of Law (S.H.) from University of Udayana DenpasarIndonesia (1985), Master of Law (M.Hum) from University of Diponegoro Semarang-Indonesia (1998),Master of Law (LL.M.) from Maastricht University The Netherlands (2009), and a Doctor of Philosophy (Dr.) from University of Diponegoro Semarang-Indonesia (2011)). 
tends to cause negative impacts in social environment such as lack of respect for the values and local culture, massive prostitution, human trafficking and sexual exploitation, large number of child laborsto unequal opportunitybetween men and women to get employed. This phenomenon is categorized as violation of human rights. Learning from this phenomenon, in the future, it is important to promote sustainable tourism.

The paper is intended to discuss in detail the sustainable development of tourism from a human right perspective for harmony and balance of rights of the actors within the tourism industries. First,what is sustainable development of tourism from a human rights perspective? Second, can human rights instruments provide a legal basis to promote sustainable development of tourism? In this context, this paper will study human rights conventions particularly the UDHR of 1948 and the conventions that govern the environment. Third, who has the responsibility to promote human rights perspective for sustainable development of tourism? Thus, this article will discuss the role of the stakeholders and their responsibility for tourism. In addition, what are the possible solutions to promote it? As a guideline of various institutions, this article will refer to possible solutions provided by the World Tourism Organization, Global Codes of Ethics for Tourism, and Voluntary Initiatives

\section{How is the concept of tourism sustainable development from the human rights perspective?}

Tourism is an activity done by an individual or a group of individuals, which leads to motion from one place to another. From a country to another for performing, a specific task or it is a visit to a place or several places in the purpose of entertaining which leads to an awareness of other civilizations and cultures, also increasing the knowledge of countries, cultures and history. ${ }^{3}$ The tourism has been growing rapidly, also with the increasing internationalization and several major benefits of globalizationin advances technology, communication, and transportation. Even, this industry considered as the top five export industries for $83 \%$ of countries. ${ }^{4}$

In regard with tourism sustainable development, the natural environment also known as "eco-tourism" 5 such as scenery, mountains, water, coral reef, ecosystem, biodiversity, including cultural heritage, economic and social systems are considered as important sources for tourism. However, for the sake of its development, ironically, it is quite often that " eco-tourism', especially in developing countriesare victims of tourism development itself, where the existence of mass different tourism's behavior and their high consumption have caused massive waste, high air and sound pollutions, and huge threats to the ecosystem and biodiversity. ${ }^{6}$ Dann and Seaton stated that in one way tourism

${ }^{3}$ Central Department of Tourism \& Summer Resorts, www.discoveralex.com/GenerslDept_EN/ Description, accessed May 20, 2011. According to World Tourism Organization (WTO, 2000, p2), tourism refers to those industries that provide accommodation, transportation and other services (e.g. the sale of souvenirs and other goods, restaurants, guided tours, etc.) for visitor who come from outside the destination for a period of more than 24 hours and less than one year. The visitors are commonly known as tourists.

${ }^{4}$ Fayed \& Fletcher, (2002). International Tourism Cultures And Behavior. In Yvette Reisinger, (2009). Oxford, UK: Butterworth-Heinemann. p. 8.

${ }_{5}$ The international Ecotourism Society defines "ecotourism" as "responsible travel to natural areasthat conserves the environment and sustains the well-being of local people.

${ }^{6}$ Treats to ecosystems and biodiversity in practice can be in the form of loss of wildlife and rare 
helps to develop the national economy while in another way it violates the basic rights of people, especially of the local people at the tourist destinations. ${ }^{7}$

Learning from the experience of tourism in developing countries, to provide better future for young generations as well as to reduce damage of environmental, local ecological, economic and social systems, it is important to pay attention and to promote the sustainable development of tourism by respecting and enforcing the whole aspects of human rights. The World Tourism Organization 1996 (the WT0) defines sustainable tourism as

"Tourism which leads to management of all resources in such a way that economic, social and aesthetic needs can be fulfilled while maintaining cultural integrity, essential ecological processes, biological diversity and life support systems. The WTO also states that the development of sustainable tourism as a process that meets the need of present tourists and host communities whilst protecting and enhancing needs in the future". ${ }^{8}$

Principle 4 of the UN Rio Declaration on Environment and Development 1992 stated "In order to achieve sustainable development, environmental protection shall constitute an integral part of the development process and cannot be considered in isolation from it". The Rio Declaration indicates that the sustainable development of the environment shall be integrated with other development processes. Concerning the development of tourism, we may define that the sustainable development of the environment shall not be isolated from various aspects of tourism's development. The concept of "sustainable development", basically, aims to upgrade the quality of both society and the environment to a satisfactory level. ${ }^{9}$ In addition, at the national level the Act No. 32 of 2009 concerning the Protection and Environmental Management, sustainable development is defined as a conscious effort and plan thatintegrate aspects of environmental, social, and economic development strategies to ensure environmental integrity and safety, skills, livelihoods, and quality of life of the present and future generations. ${ }^{10}$

Based on the concept of sustainable development above, it has actually accommodated and met the human rights aspect to promote and to protect the environment and all resources of human being such as economic, social and cultural integrity. Moreover, to understand and to recognizehuman rights perspective toward promoting the development of sustainable tourism, it may also become important to be"entitled to a healthy and productive life in harmony with nature" as pointed out through Principle 1 of the Rio Declaration 1992 on Environment and Development. In the Principle 1 Stockholm Declaration of the United Nations Conference on the Human Environment 1972 emphasized the species, habitat loss and degradation.

${ }^{7}$ Babu P. George \& Vinitha Varghese, (2007). Human Rights in Tourism: Conceptualization and Stakeholder Perspectives. EIBO Electronic Journal of Business Ethics and Organization Studies, Vol.12. No. 2, http://ejbo.jyu.fi/pdf/ejbo_vol12_no2_pages_40-48, accessed April 28, 2011.

${ }^{8}$ Kishore Shah, Jan McHarry and Rosalie Gardiner, (2002). Towards Earth Summit 2002, Sustainable Tourism-Turning The Tide, Briefing Paper. Economic Briefing No. 4, p. 1, Stakeholder Forum -UNEP, United Nations Foundation, www.earthsummit 2002.org, accessed March 2011. To understand the meaning of sustainable tourism many writers also define as eco-tourism, green travel, environmentally and culturally responsible tourism, fair trade and ethical travel.

${ }_{9}^{9}$ Marjan Peeters, (2006). Elaborating on Integration of Environmental Legislation: The Case of Indonesia. In Michael Faure and Nicole Niessen, (2006). Environmental Law in Development Lessons from the Indonesian Experience. UK: Edward Elgar Publishing Limited, p. 93.

${ }^{10}$ Article 1 (3) the Act No. 32, Year 2009 concerning Indonesian Act of Protection and Environmental Management. 
association of sustainable development with human rights. This UN Conference declared that "man has the fundamental right to freedom, equality and adequate condition of life, in an environment of a quality that permits a life of dignity and well-being, and he bears a solemn responsibility to protect and improve the environment for present and future generation. ${ }^{11}$ Simply, it may be considered that in the context of human rights perspective for tourism sustainable development shall refer to promote and respect the fundamental right of every human being as well as entitled to get peaceful and harmony life with nature including economic, social and cultural dignity not only for current situation but also more importantly for future generations.

To keep these resources still available both for basic needs of current purposes and future generation, therefore it is very important that the whole stakeholders who involved in tourism process getting aware to promote, respect, and enforce the human rights instruments for sustainable development of tourism. According to Sautter and Leisen, stakeholders are parties in the macro or microenvironment who are concerned with human rights and can impose human right for implementation and tourism monitoring. The important stakeholders in tourism process identified as the comm. unities at destination, the employees, the companies, the tourists, the governmental, and the nongovernmental organizations. ${ }^{12}$

\section{Whether Human Rights instruments provide legal basis to promote sustainable development of tourism?}

As already discussed previously,sustainable development of tourism covers all resources for the basic needs of human beings, therefore in the paper we only focus on discussing some crucial fundamental needs of tourism activities. They are namely natural environment, economic, social, and cultural dignities.

Generally, authors in the most literatures have categorized human rights into three generations. The first generation is civil and political rights based on the principle of liberty. The second generation is economic, social and cultural rights based on the principle of equality. The third generation is rights of solidarity based on the principle of fraternity. To first and second generations belongto individual human rights while the third generation is collective human rights.

The right to a clean or healthy environment is one of the most prominent examples of human rights of the third generation. ${ }^{13}$ More specifically as a collective right, Article 24 of the African Charter on Human and Peoples' Rights states that all people shall have the right to a general satisfactory environment favorable to their development. ${ }^{14}$ Although the right to a clean environment has been formulated as collective rights, it can also be formulated asan individual human rights. ${ }^{15}$ There are some human rights instruments which provide legal

\footnotetext{
${ }^{11}$ Patricia Birnie, Alan Boyle, Catherine Redgwell, (2009). International law \& the Environment, New York: Oxford University Press. p. 271.

${ }^{12}$ Supra Note 7, p. 41.

${ }^{13}$ Christian Tomuschat, (2008). Human Rights Between Idealism and Realism. New York: Oxford University Press. p. 54.

${ }^{14}$ Sandy Ghandhi, (2008). Blackstone's International Human Rights Documents 6 th Edition. Online Resource Centre. New York: Oxford University Press. p. 404.

${ }^{15}$ Bulent Algan, (2004). Rethinking "Third Generation" Human Rights, Ankara Law Review, Vol:1
} 
basis for sustainable clean environment of humankind as individual. Principle 1 of the Declaration of Stockholm 1972 states that man has the fundamental right to freedom, equality and adequate conditions of life, in an environment of a quality that permits a life of dignity and well-being. The 1982 World Charter for Nature is the first instruments to recognize the right of individuals to participate in decision-making and have access to means of redress when their environment has suffered damage or degradation. Furthermore, the UN General Assembly Resolution 45/94 (1990) has declared that all individuals are entitled to live in an environment adequate for their health and well-being. Then, the UN Commission on Human Rights Resolution 1990/41 has affirmed the relationship between the protection of the environment and the promotion of human rights. ${ }^{16}$

The UN Covenant on Economic and Social Rights of 1966 as the second generation of human rights also promote the environment for health and wellbeing. Article 12 recognizes the right of everyone to the enjoyment of the highest attainable standard of physical and mental health through the improvement of all aspects of environmental and industrial hygiene. The Global Codes of Ethics for Tourism Year 1999, ${ }^{17}$ more specifically Article 3, although known as non legal binding instrument, has pointed out that "all the stakeholders in tourism development should safeguard the natural environment with a view to achieving sound, continuous and sustainable economic growth geared to satisfying equitably the needs and aspirations of present and future generations". Although this Global Code is not a specific human rights instrument, its substance actually meets with human rights aspects, especially the right to respect the family and private life as in Article 8 of the European Convention for the Protection of Human Rights and Fundamental Freedoms.

Other aspects of tourism activities which is linked to human rights are economic, social and cultural rights. Beside provided by the UN Covenant on Economic and Social Rights 1966, actually some direct legal instruments for tourism can be found in the Universal Declaration of Human Rights (UDHR) adopted by the UN General Assembly in 1948 more specifically Article 13 and Article 24. As we know, that the core of tourism is motion or movement of people therefore that activities can be covered by Article 13 UDHR, which states that everyone has the right to freedom of movement and residence within the borders of each State. Similarly directly addressed to tourism, is Article 24 of the UDHR which declares that "everyone has the right to rest and leisure, including reasonable limitation of working hours and periodic holidays with pay". This instrument suits not only upon "the right to tourism" for tourists but also for the employees. To promote fundamental human rights related to tourism activities elaborate Article 1 until Article 11 and Article 23 of the UDHR are also relevant.

In detail, Article 1 of the Universal Declaration of Human Rights (1948) stated that "All human beings are born free and equal indignity and rights. They are endowed with reason and conscience and should act towards one another in a spirit of brotherhood. Article 23 of the UDHR stated:

1. Everyone has the right to work, to free choice of employment, to just and

\footnotetext{
(Summer 2004), p. 130.

${ }^{16}$ Philippe Sands, (2003). Principles of International Environmental Law. UK: Cambridge University Press. p. 294-295.

${ }^{17}$ Global Code of Ethics for Tourism adopted by resolution A/RES/406(XIII) at the thirteenth WTO General Assembly (Santiago, Chile, 27 September - 1 October 1999.
} 
favorable conditions of work and to protection against unemployment

2. Everyone, without discrimination, has the right to equal pay for equal work

3. Everyone who works has the right to just and favorable remuneration ensuring or himself and his family an existence worthy of human dignity, and supplemented, if necessary, by other means of social protection.

4. Everyone has the right to form and join trade unions for the protection of his interests.

From those article above we can understand that if people work wherever they work, including in tourism sector from the human rights perspective they should have equal right and not discriminated each other.

As pointed out by Bruner tourism activities are notorious for maltreating workers and sustaining a master-slave model of relationship between tourists and workers. ${ }^{18}$ The UDHR Article 3 until Article 5 also International Covenant on Civil and Political Rights (ICCPR) Article 6 until Article 8, provide legal basis for the right to life, liberty, and the right not to be subjected to torture or to cruel including slavery in all forms. Cruel and inhuman treatment in all forms of sexual trading and trafficking tend to increase in tourism destinations. People who work or who deal with tourism activities including all tourism stakeholders should have protection for not to be torture because they have fundamental right as we know as the right to life and liberty.

Concerning the right to life Article 6 of the International Covenant on Civil and Political Rights (ICCPR) in detail stated ${ }^{19}$ :

1. Every human being has the inherent right to life. This right shall be protected by law. No one shall be arbitrarily deprived of his life.

2. In countries which have not abolished the death penalty, sentence of death may be imposed only for the most serious crimes in accordance with the law in force at the time of the commission of the crime and not contrary to the provisions of the present Covenant and to the Convention on the Prevention and Punishment of the crime genocide. The penalty can only be carried out pursuant to a final judgment rendered by a competent court.

3. When deprivation of life constitutes the crime of genocide, it is understood that nothing in this article shall authorize any State Party to the present Covenant to derogate in any way from any obligation assumed under the provisions of the Convention on the Prevention and Punishment of the Crime of Genocide.

4. Anyone sentenced to death shall have the right to seek pardon or commutation of the sentence. Amnesty, pardon or commutation of the sentence of death may be granted in all cases.

5. Sentence of death shall not be imposed for crimes committed by persons below eighteen years of age and shall not be carried out on pregnant women.

6. Nothing in this article shall be invoked to delay or to prevent the abolition of capital punishment by any State Party to the present Covenant.

The Convention for the Suppression of the Traffic in Persons and of the Exploitation of the Prostitution of Others (1949) can also be imposed for

${ }^{18}$ Bruner, (1996). In Supra Note 7, p. 44.

${ }^{19}$ Sandy Ghandhi, 2008, International Human Rights Documents 6th Edition, Oxford University Press, New York, p. 41. 
the violation of human rights in tourism activities related with all forms of prostitutions.

In addition, Article 2 (3) the Global Codes of Ethics for Tourism also energetically promote to combat the exploitation of human being in any form, particularly sexual, especially when applied to children, conflicts with the fundamental aims of tourism.

The right to work including the right to tourism can be found in the Article 6 and 7 of the ICESCR as well as the UDHR Article 23 and 24. The UNWTO Global Codes of Ethics for Tourism through Article 7 and Article 8 promote and respecting the right to tourism and Article 9 for the right to work. Article 7 of the UN WTO Global Code of Ethics for Tourism concerning Right to Tourism mentioned that ${ }^{20}$ :

1. The prospect of direct and personal access to the discovery and enjoyment of the planet's resources constitutes a right equally open to all the world's inhabitants: the increasingly extensive participation in national and international tourism should be regarded as one of the best possible expressions of the sustained growth of free time, and obstacles should not be placed in its way.

2. The universal right to tourism must be regarded as the corollary of the right to rest and leisure, including reasonable limitation of working hours and periodic holidays with pay, guaranteed by Article 24 of the Universal Declaration of Human Rights and Article $7 \mathrm{~d}$. of the International Covenant on Economic, Social and Cultural Rights;

3. Social tourism, and in particular associative tourism, which facilitates widespread access to leisure, travel and holiday, should be developed with the support of the public authorities;

4. Family, youth, student and senior tourism and tourist for people with disabilities, should be encouraged and facilitated.

Respecting and promoting the cultural heritage of humankind is one of the important aspects in processing tourism. Article 22 of the UDHR and Article 15 of the ICESCR provide a legal basis to participate in respecting cultural life. Similarly, Article 4 of the Global Codes of Ethics for Tourism Year 1999 also quite clear promote respecting to the culture heritage of mankind by mentioning that:

1. Tourism resources belong to the common heritage of mankind: the communities in whose territories they are situated have particular rights and obligations to them;

2. Tourism policies and activities should be conducted with respect for the artistic, archaeological and cultural heritage, which they should protect and pass on to future generations; particular case should be devoted to preserving and upgrading monuments, shines and museums as well as archaeological and historic sites which must be widely open to tourist visits; encouragement should be given to public access to privately-owned cultural property and monuments, with respect for the rights of their owners, as well as to religious building, without prejudice to normal needs of worship;

3. Financial resources derived from visits to cultural sites and monuments should, at least in part, be used for the upkeep, safeguard, development and

${ }^{20}$ The UN WTO, Global Code of Ethics for Tourism, Capitain Haya 42, Madrid, p. 15. 
embellishment of this heritage;

4. Tourism activity should be planned in such a way as to allow traditional cultural products, crafts and folklore to survive and flourish, rather than causing them to degenerate and become standardized.

As we know, the UNWTO Global Codes of Ethics for Tourism is a soft law. Consequently, it is nota legal binding instrument. Utilizing this soft law to promote and respect human rights in tourism activities will fall under voluntary basis. It is likely more moral binding rather than legal binding except a State (Government) adopts these Codes into its national law then it will becomes binding legal instrument. ${ }^{21}$

Although this Global Codes of Ethics for Tourism has made very clear that it does not want to be prescriptive and legalistic in its approach to such rights, there is no reason why the spirit of the document cannot be reflected in particular laws. The benefit of the UN WTO Code of Ethics (whatever its failings) is that in makes visible in a quasi-regulatory context, the host community. ${ }^{22}$ In national level, Indonesia for example does not mention explicitly that it has adopted the UNWTO Global Codes of Ethics for Tourism. However, Article 19 until 26 of the Act No. 10 of 2009 concerning Tourism have clearly reflected the substance of the UNWTO Global Codes of Ethics, more particularly at the Preamble and its explanation. Therefore, in case of Indonesia, it can be said that the benefit of the UNWTO Codes through national law becomes legal binding.

\section{Who has the duty to promote human rights perspective for sustainabledevelopment of tourism?}

Tourism activities need massive resources and tend tobe land-intensive. Consequently, there are frequentlyconflicts took place between the local community and tourism entrepreneurs in regard to use of the land and other interest of natural resources. Tourism Concern and Rethinking Tourism (NGO's) has reported that tourism developments often stop people from having the right of access to land, water and natural resources. Similarly, in the context of the social and cultural, some Articles in the UDHR are violated where exploitation occur of indigenous rights, low wages, child labor, and sex trading in the tourism sector occurs. ${ }^{23}$ Tourism has become associated with violation of human rights. ${ }^{24}$ Accordingly, to create harmony with an attitude of tolerance and to balance the needs and aspirations of present and future generations, promoting tourism sustainable development from human rights perspective become an alternative solution to minimize or even to avoid human rights abuses in the tourism sectors. The question is who has the duty to do it and who has the responsibility?

The Global Codes of Ethics for Tourism,more explicitly Article 3, states that "All stakeholders in tourism development should safeguard the natural environment with a view to achieving sound, continuous and sustainable economic growth geared to satisfying equitably the needs and aspirations of

\footnotetext{
${ }^{21}$ Violetta Simatupang, (2009). Pengaturan Hukum Kepariwisataan Indonesia (The Legal Arrangement of Indonesian Tourism). Bandung, Indonesia: PT Alumni. p. 45.

${ }^{22}$ Peter M. Burns and Marina Novelli, (2006). Tourism and Social Identities Global Frameworks and Local Realities. The Netherlands: Elsevier Ltd. p. 9.

${ }^{23}$ Supra Note 8, p.5.

${ }^{24}$ The UNCSD NGO Committee, (1999). Tourism and Sustainable Development, Sustainable Tourism: A Non-Governmental Organization Perspective. New York: Department of Economic and Social Affairs. p.2.
} 
present and future generations. In detail Article 3 of the UN WTO Global Code of Ethics with the title of "Tourism, a factor of sustainable development" stated that:

1. All the stakeholders in tourism development should safeguard the natural environment with a view to achieving sound, continuous and sustainable economic growth geared to satisfying equitably the needs and aspirations of present and future generations;

2. All forms of tourism development that are conducive to saving rare and precious resources, in particular water and energy, as well as avoiding so far as possible waste production, should be given priority and encouraged by national, regional and local public authorities;

3. The staggering in time and space of tourist and visitor flows, particularly those resulting from paid leave and school holidays should be sought so as to reduce the pressure of tourism activity on the environment and enhance its beneficial impact on the tourism industry and the local economy;

4. Tourism infrastructure should be designed and tourism activities programmed in such a way as to protect the natural heritage composed to ecosystem and biodiversity and to preserve endangered species of wildlife, the stakeholders in tourism development, and especially professionals, should agree to the imposition of limitations or constraints on their activities when these exercised in particular areas sensitive: desert, polar or high mountain regions, coastal areas, tropical forests or wetlands, propitious to the creation of nature reserves or protected areas.

As already mentioned above that although the UN WTO Global Code of Ethics is not a human rights legal instrument, however morally this code can be used as starting point to determine which parties actually haveto bear the duties? Accordingly, all stakeholders who are involved in the tourism sectors morally have duty-bears, although for the right to clean environment as part of the third human rights generation is surrounded by grave uncertainties regarding the duty-bearers.

\section{A. Promoting health and a clean environment}

Fair trade in tourism is one of the important key aspects of sustainable tourism. Among the entrepreneurs or the companies and the local communities, have to perform a fair business competition as well as sustainable use of the natural resources in regard of eco-tourism. Tourism companies should empower to adopt environmentally sound eco-friendly technologies or other measures to minimize the consumption of natural resources. For example, by utilizing the rainwater for watering hotels' gardens instead of the ground water such as local ground water for example by utilizing rainwater for hotel gardens. ${ }^{25}$

It is important to learn, to respect, and to adopt as well as to involve the local communities at destination regarding how the way they conserve their natural recourses. In this context, Bali has the best practice in empowering water for land irrigation by utilizing the water system known as "Subak Water System." ${ }^{26}$ Simply, in practice farmers can use water together in their terrace

${ }^{25}$ Supra Note 21, p. 2 .

${ }^{26}$ Subak Water System is the name of water management (irrigation) system for paddy fields on Bali Island. For Balinese irrigation is not simple providing water for the plant's roots, but water is used to 
sharing land fields. The water flows from the top to down terrace sharing land field. The value and philosophy of this system can be adopted and enforced for the needs of hotels garden by empowering own recycled waste water system not only for huge hotels but also for medium and small ones.

Another example in Bali, of the way in which of local community respect their natural environment known as "The Silent Day," where one day is organized without transportation or other industries pollution. It is an example of the local community respecting their natural environment that associate with the right to a clean environment. This value of Balinese societies in respecting the macro and micro cosmos may also be adopted as a possible solution by other tourism areas in the world to promote and respect the rights to a clean environment. Of course, it needs to be campaigned that all stakeholders (local communities, entrepreneurs, employees, tourists, governments, and NGOs) have duty to promote and respect this measures.

In general, to minimize the negative impacts of tourism activities related to eco-tourism, consequently ecological methods need to be applied in all sector of tourisms both traditional and modern methods.

Partnerships and "Voluntary Initiatives for Sustainable Tourism" also have an important role to promote human rights related to healthy and a clean environment. The "Agenda 21 for the Travel \& Tourism Industry: Towards EnvironmentallySustainable Development" stressed thatPartnerships Initiatives between Government, Industry and NGOs such as UNEP with Ecotourism Society, UNEP Partnership with the Hotel Industry, UNEP with UNESCO World Heritage Centre is also implementing sustainable tourism components in World Heritage Sites in Mexico, Guatemala, Honduras and Indonesia.

Some studies have indicated that important stakeholders such as tourism industry have neither willingness nor awareness to take steps to implement their duty in promoting sustainable development of tourism. On the contrary, the local communities at the destination area are also often not aware of their rights such as the right to a clean environment as well as the rights to be informed in the case of any sound (noise), air, and nuclear pollution as covered by various articles within the second and the third generation human rights. Therefore, it becomes very important to disseminate whatever measures have been taken as part of promoting sustainable tourism to all stakeholders in tourism sector. The question is again who has the duty to do it? Government and Voluntary Partnerships can conduct effectively these activities because besides they morally or even legally have already pointed out in various legal instruments or code of conducts they are also supported by strong power and sufficient finance.

In case of pollution, the absence of informing the public of extreme noise (sound pollution), for example due to the construction of an airport to support the massive development of tourism at the destination area especially during the night and by ensuing decreasing value of family homes, canbe considered as a violating the human rights. There are important lessons from the European Court of Human Rights in examining environmental cases. The court held that the absence of informing the public of extreme noise as in the Hatton casecan be considered as a violation of Article 8 concerning the right to respect had

construct a complex, pulsed artificial ecosystem. 
been family and private life. ${ }^{27}$ A Chamber of the Court found that Article 8 of the European Convention for the Protection of Human Rights and Fundamental Freedom violated. Similarly, the Grand Chamber of the Chamber decided that a violation had occurred. ${ }^{28}$ Lesson from the decision in the Hatton Case, is that a State has a positive obligation to offer protection for its citizens in regard to the right to respect family and private life and it becomes the responsibility of the State when a human rights violation has occurred because of the State'shad failed to protect citizens..

In addition, it can be said that to determine who has the duty to promote the right to decent, healthy, or a satisfactory environment is not merely to be found by observing the right to clean environment that fall under uncertainties of the third human rights generation itself. Environmental rights can also usefully be derived from other existing treaty rights. In particular, the rights to life, private live, and access to justice under the UN ICCPR 1966 Article 6(1), 14(1) and Article 17. Similarly, it can be seen under Article 2, 6(1), and Article 8 of the European Convention on Hhuman Rights. By utilizing those treaties it is clear that every human can be right holder and that the State (Government) through its positive obligation has the duty and can be compelled towards compliance in case of violations of human rights. Some famous cases in this context were decided by the European Court on Human rights such as Lopez Ostra v Spain (1994) 20 EHRR 277, Guerra v Italy (1998) 26 EHRR 357, and Fedeyeva v Russia (2005) ECHR $376 .^{29}$

\section{B. Promoting the right to tourism and the right to work}

Among various areas of human rights, the right to tourism does not attract much attention and is little discussed by legal doctrine. It may be since these human rights are not considered as fundamental as other human rights such as the right to life. However, in the form of sustainable tourism this human right has an important meaning.

The World Tourism Organization (WTO) provides a definition of tourism by referring to the concept of tourism and visitor at the Ottawa International Conference 1993. According to the WTO, tourism is the activities of persons traveling to and staying in places outside their usual environment for not more than one consecutive year for leisure business and other purposes. While the visitor is defined as persons those who travel to a country other than that in the which they have their usual residence but outside their usual environment for a period not exceeding twelve months whose mind and purpose of visit is other than the exercise of an activity remunerated from within the place visited. ${ }^{30}$

The definition of tourism and the visitor as referred to in the UN WTO Global Code of Ethics if it is associated with the Law of Tourism in Indonesia, it seems the definition is closer to the definition "tourism", although in Indonesia travel restrictions to tourism only mentioned within a period of "temporary", whereas in the definition of the UN WTO Global Code of Ethics explicitly mentioned limits

${ }^{27}$ Aalt Willem Heringa, (2006). Human Rights and General Principles and Their Importance as a Legislative Technique. Do they matter in legislation? An analysis with specific reference to environmental protection. In Michael Faure and Nicole Niessen, (2006). UK: Edward Elgar Publishing Limited. p.17.

${ }^{28}$ ECtHR, 8 July 2003, Hatton and others v. United Kingdom (Hatton 2).

${ }^{29}$ Supra Note 11, p. 283.

${ }^{30}$ Charles R. Goeldner, J. R. Brent Ritchie, (2009). Tourism, Principles, Practices, Philosopher, Part One. Canada: John Wiley \& Sons. www.mccoy.lib.sie.edu, accessed 10 August 2011. 
of "no more than one year". From the concept of "tourism" which is expressed both in the context of the UN WTO Global Code of Ethics that has been clearly put forward about the duration of visit was "nothing more than a year" or in the context of "travel" according to the Law of Tourism in Indonesia that deadlines/ the length/duration of stay is "temporary". Therefore, as of this holiday seasons, the human rights issues in tourism can be studied. The questions then what human rights issues come up relating to tourism.

From the definition of "travel" or "tourism" according to the law in Indonesia or "tourism" according to the UN WTO, it can be drawn elements of the tourism or travelling as follows:

1. The activities of travel (traveling) from a person for purposes of recreation or fun (leisure)

2. Recreational activities for fun conducted outside the workplace or residence through the activities of daily trips (moving traveling or movement)

3. Activities for the purpose of leisure conducted no more than one year.

By observing those elements that existed in the context definition of "tourism" or "travel" as mentioned above, either in the Law of Tourism in Indonesia and in the UN WTO Global Code of Ethics for Tourism, it is very clear that tourism is expressed as part of Human Rights. Currently, many things are added as part of human rights including the right to tourism. Actually it is doubtful to accept that tourism as a part of human rights, considering there are still many fundamental rights that people have a much more worthy to be fulfilled, promoted and respected for the sake of human dignity. But in Indonesia through Act No. 10 Year 2009 Concerning Tourism has recognized that the freedom to travel and enjoy free time in the form of tourism is part of human rights.

In the Law of Tourism in Indonesia regulation on sustainable development set forth in the section "Consideration the letter c" which states that tourism is an integral part of national development is done in a systematic, well planned, integrated, sustainable, and responsible while providing protection against the values religions, cultures living in the community, sustainability and environmental quality, as well as national interests.

Related to the achievement of sustainable tourism development, there are three important pillars that must be considered and harmoniously maintained, that is: the balance of economic, environmental and social pillars coupled with climate change. The issues of climate change have an influence either directly or indirectly to the development of economic and social culture. ${ }^{31}$

The issue of climate change is closely associated with environmental aspects. In conjunction with the negative impacts of climate change then in the framework of sustainable tourism development also is heavily promoted on ecotourism development. Ecotourism is often defined in a flexible, however briefly it can be stated that ecotourism defined as "responsible travel to natural areas that conserves the environment and sustains the well-being of local people". ${ }^{32}$

The obligation and responsibility to the environment seems to always

\footnotetext{
${ }^{31}$ Navamin Chatarayamontri, (2009). Sustainable Tourism And The Law: Coping With Clime Change, Dissertation \& Theses. Paper 6, http://digitalcommons.pace.edu/lawdissertations, p2

${ }^{32}$ Karen Roach, "The International Year of Ecotourism: Tackling the Challenges of Global Regulation", Suffolk Transnational Law Review 191, (2011). p.2.
} 
exist in a variety of concepts concerning the development of tourism, both as tourism, ecotourism or sustainable development. Moving on from these concepts then the existence of human rights aspects in the activities of "tourism" in the broader context of "tourism activity" or tourism can be stated as follows: the right to clean environment, the right to work, the right to life, and the right to tourism. From those description above we no doubt to state that tourism is very close related with human right, as in the UN WTO Global Code of Ethics it mentions through Article 7 concerning the right to tourism.

According to the United Nations World Tourism Organization Global Code of Ethics for Tourism especially Article 7(2), the universal right to tourism must be regarded as the corollary of the right to rest and leisure, including the reasonable limitation of working hours and periodic holidays with pay. The right to tourism is guaranteed by Article 24 of the Universal Declaration of Human Rights and Article 7 (d) of the International Covenant on Economic, Social and Cultural Rights. Thinking about a human right to tourism, generally will attract people to look for the human rights from a tourist perspective. A corollary to the human right of tourists is also about right to confidential data, right to gaininformation, right to get sufficient foreign exchange, right to have access to all available forms of communication internally or externally, etc. More importantly, according to Article 8 of the UN WTO Global Code of Ethics for Tourism, there are the rights of liberty for tourist to move within their countries and from one state to another, in accordance with Article 13 of the Universal Declaration of Human Rights.

In contrast, while discussing the right to tourism for tourists we may ignore the right of employees who work at the tourism destination. Tourists enjoy their rights such as relaxing in the sunshine, swimming at the swimming pool of the luxurious hotel, and drinking beer at the bar. But, life is far from paradise for the employees. Actually as a human being the employee also has the same "human rights to tourism" as tourist does. In the Preamble, it is also very clear stated that "aiming to promote responsible, sustainable and universally accessible tourism in the framework of the right of all persons to use their free time for leisure pursuit or travel with respect for their choices of society of all peoples." It can be extended "all persons" also means the employees also have the right to tourism. In addition, as an employee according to Article 9 of the UNWTO Global Codes of Ethics for Tourism, they have fundamental rights of salary, appropriate training and entitled to develop a professional activity, and exchange of experience offered to executives. Fundamental freedoms for all without distinction as to race, sex, language or religion is also inherent of the employees because they are human being. Taking into account in the case of the notion of the soft law has already been adopted into national law in Indonesia, without doubtit can be undoubtedly said that to promote the right to tourism and the right to work in the context of sustainable tourism will be the duty of all stakeholders, more importantly the duty of tourism professionals and the public authorities. In detail, it can be examined an example of the duty of each stakeholder through some Articles of the Indonesian Act No. 10 of 2009 as follows:

1. According to Article 23 (1) of the Act No. 10 of 2009 states that the Government and the Local Government have obligation to provide tourists with objective and honest tourism information on their destination, legal 
protection, security and safety to the tourists.

2. Furthermore, Article 24 a, of the Act No. 10 of 2009 emphasizes that every human has an obligation to keep and protect the sustainable of the environment and the enjoyment of the tourism destination.

3. Concerning the duty of the tourist, the Indonesian Tourism Law has pointed out through Article 25 a. This Article mentions that every tourist has an obligation to protect and to respect the religious, custom, cultural, and the local values of the host communities.

4. Finally, Article 26 of the Act No. 10 of 2009 states that every professional tourism has an obligation to protect and respect the religious norm, customs, cultural, and the local values of the host communities.

In addition, by extending Article 24 of the UDHR and Article 7 of the ICCPR for the right to tourism, and by exploring Article 6 and Article 7 of the ICESCR and Article 23 of the UDHR for the right to work at the tourism activities, it is clear that everyone or every human can be a rights holder and the State has the duty to promote it.

As stated before that in general all stakeholders have responsibility to promote human rights for sustainable development of tourism sector. Especially for business actors or corporations who conducting business in the tourism sectors some soft laws instruments also emphasizes the strong point of the responsibility of corporation to respect, protect and fulfill human rights.

In the form of Soft Law, the UN WTO Global Code of Ethics have regulated very clear how business actors should behave when conducting their activities including they should respect and protect human rights. Beside the UN WTO Global Code of Ethics, UN Human Rights Council also endorses principles to ensure that business pay respect to human rights. This new set of principles known as the United Nations (UN) Special Representative, "Guiding Principles on Business and Human Rights: Implementing the United Nation "Protect, Respect and Remedy". The framework of John Ruggie principles is based on three pillars namely ${ }^{33}$

1. TheState duty to protectagainsthuman rights abuses bythird parties, including business through appropriate policies, regulation, and adjudication.

2. The corporate responsibility to respect human rights which mean avoiding the infringement on the rights of others and address adverse impacts that occur.

3. Greater access by victims to effective remedy, both judicial and non-judicial:

To ensure and against wrongful conduct of business actors there are some human rights instruments can be applied such as the Set of Norms on the Human Rights Responsibilities of Transnational Corporations and Other Business Enterprise. Since the emergence of MNCs in the globalization era, ${ }^{34}$ there are still lot of discussion whether the holding companies which have headquarter abroad are liable for such human rights abuses which enormously committed by

${ }^{33}$ John Ruggie, (2011). UN Guiding Principles for Business \& Human Rights. Kennedy School of Government and Harvard Law School, http://lw.harvard.edu/corpgov/2011.

${ }^{34}$ Globalization can be considered as the framework of economic growth and social progress. Economic growth in one hand may increase the resource available for the realization of human right it gives positive effects on the protection and promotion human right, on the other hand globalization also bring negative effects for the enjoyment of human rights. 
its subsidiary companies in certain countries. Many scholars conducted research concerning this phenomenon, ${ }^{35}$ especially after the activities of MNCs brought much negative impact, both for environment as in the Bhopal case and human rights. Many researchers consider that the matter of observing liability of MNCs under international law is necessary. Concerning the liability of corporation, both hard law and soft law, may apply. For instance through soft law, the duty to promote and protect human rights under the Preamble to the UDHR can be applied to all corporations, as important 'organs of society', regardless of the range of their operations. ${ }^{36}$ The last article of the Preamble of UDHR makes clear the liability of corporations in human Rights violations. This Preamble states that "Nothing in this Declaration may be interpreted as implying for any State, group or person any right to engage in any activity or to perform any act aimed at the destruction of any of the rights and freedoms set forth herein." MNCs or domestic corporations can be interpreted as group or person pursuant to last Preamble of the UDHR ${ }^{37}$. By studying the human rights instruments above it is very clear that the wrongful conduct of business actors can be solved through Human Rights approaches.

Besides applying soft law and hard law as part of state regulations, actually the balance of self regulatory creating by tourism sector will bring different atmosphere of law enforcement in tourism activities. Related with self regulation, the question then whether the self regulation harmony with the state regulation, the effectiveness of these regulations will be very important to protect and provide better future of the business activities in tourism sector for all stakeholders including communities at host destination.

In general, the new era development of corporate liability can be classified as corporate social responsibility and corporate legal liability.

\section{The Corporate Social Responsibility}

The concept of Corporate Social Responsibility (CSR) has been developed since the early 1970's, however, until now none of standard definition we can find related with the CSR (there is no single commonly accepted definition of CSR). Through several literatures which is emphasizes the role of CSR for all stakeholders and for the sustainability of the company itself, the CSR defined as follows:

According to Maignan\& Ferrell, CSR is defined as: "A business acts in socially responsible manner when its decision and actions account for and balance diverse stakeholder interests". ${ }^{38}$ Philip Kotler and Nancy Lee defined CSR is a commitment to improve community well-being through discretionary business practices and contributions of corporate resources. In this context CSR is a corporate commitment to improve the livelihoods of communities through

\footnotetext{
${ }^{35}$ Some scholars who conducted research in the liability of multinational corporations such as Menno T. Kamminga -Saman Zia-Zarifi, Viljam Engstrom, Craig Scott, and many others.

${ }^{36}$ Menno T. Kamminga and Saman Zia-Zarifi, (2000). Liability of Multinational Corporations under International Law. The Netherlands: Kluwer Law International. p. 3.

37 Viljam Engstrom, (2002). Who is Responsible for Corporate Human Rights Violations? Abo Akademi University Institute for Human Rights. p. 26.

${ }^{38}$ A.B. Susanto, (2009). Reputation-Driven Corporate Social Responsibility Pendekatan Strategic Management dalam CSR. Esensi, Erlangga, p. 10.
} 
good business practices and contributions of corporate resources. ${ }^{39}$ According to Philip Kotler\& Nancy Lee, an important element of CSR is "discretionary" is not referring to the mandated by law or that are morals or ethical in nature. It means CSR more concerning a voluntary commitment from a business activity that is implemented in business activities as a contribution of the company for their stakeholders. Furthermore, italso stated that the meaning of "community well-being" in the concept of CSR is the contribution of the company in improving the quality of the human condition and environmental issues.

John Elkington defined CSR through the concept of the Triple Bottom Line. According to him the company that wants to pursue a business must consider the 3P: Profit, People, and Planet. In conducting business, the company is no longer just has responsibility based on a "single bottom line", namely the economic aspects are reflected in the financial condition of the profit-only (Profit), but the company also must pay attention and get involved and show social responsibility by paying attention to the fulfillment of prosperity and quality of surrounding communities, especially communities (People), as well as actively contributing to protecting the environment (the planet - the Earth). ${ }^{40}$ In the context of $3 \mathrm{P}$, John Elkington argued that business is sustainable when it lives up to the "triple bottom line" of economic prosperity, environmental quality and social justice. ${ }^{41}$

Archie B. Carroll explained the concept of CSR through the pyramid of corporate social responsibility as follows: Philanthropic Responsibilities (be a good corporate citizen, contribute resources to the community, and improve quality of life), Ethical Responsibilities (be ethical. Obligation to do what is right, just, and fair, and avoid harm), Legal Responsibilities (obey the law. Law is society's codification of right and wrong. Play by the rules of the game), and Economic Responsibilities (be profitable. The foundation upon the all others rest). ${ }^{42}$ In this pyramid, Carroll suggests economic responsibility as its foundation, then the legal responsibility, ethical responsibility, and on top of the pyramid there is philanthropic responsibility.

The Concepts and definitions of CSR can also be understood through the definitions set out by International Organizations. According to the World Business Council for Sustainable Development (WBCSD), CSR is put forward in 1998 in the CSR dialogue in the Netherlands defined as: continuing commitment by business to behave ethically and contribute to economic development while improving the quality of life of the workforce and their families as well as of the local community and society at large. The World Bank put forward; Companies are realizing that it is their business interests to "do the right thing" they operate everywhere. Global firms are keenly that their long-term investment goals can only be achieved within a stable, healthy and free of social and financial environment. But companies alone can not solve the challenges associated with social responsibility. They must work in cooperation with Governments, civil society groups, development institutions, and citizens. In this case the World Bank stressed that the company should be aware of the importance of doing

\footnotetext{
${ }^{39}$ Philip Kotler \& Nancy Lee, (2005). Corporate Social Responsibility, Doing the Most Good for Your Company and Your Cause. Canada: John Wiley \& Sons Inc. p. 3.

${ }^{40}$ Gunawan Widjaja \& Yeremia Ardi Pratama, (2008). Resiko Hukum \& Bisnis Perusahaan Tanpa CSR. Jakarta: Forum Sahabat. p. 33.

${ }^{41}$ John Elkington, (1997). Book reviews of Cannibals With Forks: the Triple Bottom Line of 21st century Business, http://www.springerlink.com, accessed 9 April 2011.

${ }^{42}$ Amin Widjaja Tunggal, (2008). Corporate Social Responsibility. Jakarta: Harvindo. p. 57.
} 
good deeds wherever they operate. The success and sustainability of a business would be achieved if the company concerned and allocated for social programs including health and environmental sustainability. In this context, companies can not work alone, but with support from governments, NGOs, or other institution and the community. The concept of CSR is also suggested by the United Nations. Company according to the UN has obligation for social and moral obligation to seek global conditions for the better through its market power. Cooperation have a social responsibility and moral duty to use the power of markets to make globalization a positive force for all.

At the European regional level, through the European Commission, Promoting a European Framework for Corporate Social Responsibility, Green Paper, stated that CSR is a concept where thecompanies integrate social and environmental concerns in business operations and in their interaction with stakeholders on a voluntary basis. The concept of CSR in this case is voluntary of the company to perform social responsibilities. According to the European Union, CSR is the concept that an enterprise is accountable for its impact on all relevant stakeholders. It is the continuing commitment by business to behave fairly and responsibly and contribute to economic development while improving the quality of life of the work force and their families as well as of the local community and society at large. In line with its CSR concept of European Union, in America through the Global Corporate Accountability Programs for the New York-based Center of Corporate Responsibility mentioned that "the principles for global corporate responsibility call on companies to base their corporate policies on a vision of themselves as one of many stakeholders in the global community and to set high standards of conduct in relation to their employees, the environment, and the communities which they operate." ${ }^{43}$ In this contexts emphasized the important of fulfillment the standards-based company based on good relationships with employees, the environment and surrounding community, especially in the location of company take place.

Concerning CSR in the national level, as in Indonesia, formally through Article 74 of Law No. 40 of 2007, stated that:

1. The Company is running its business activities in the field and / or relating to natural resources, shall exercise social responsibility and environmental responsibility.

2. Social and environmentalresponsibilities as referred to in paragraph (1), are obligation of the Company, budgeted and regarded as the costs of their implementation, carried out with due regard to decency and fairness.

3. The company which does not carry out the obligation as referred to in paragraph (1) are subject to sanctions in accordance with the provisions of the legislation

4. Further provisions on Social and Environmental Responsibilitiesregulated by Government Regulation.

Based on the Company LawNo. 40 of 2007, the obligation to implement CSR in Indonesia is intended only for the company which its entity is "PT" or corporation. However, according to Investment Law No. 25 of 2007not only Corporation (PT) but also individual company (sole proprietor that doing

${ }^{43}$ CSR main Concept, www.ecrg.org.eg/CSR.main.concepts.pdf, p.3, accessed 10 July 2011. 
business activities in capital investment. Under the Article 15 (b) Act No. 25 Year 2007 concerning Capital Investment stated that: "Every investor is obliged to implement corporate social responsibility".

According to the explanation of Article 15 (b) the term "corporate social responsibility" is a responsibility inherent in each investment companies to keep creating a harmonious, balanced, and in accordance with the environment, values, norms, and culture of local communities. Meanwhile, Article 1 (4) states that investor is an individual or business entity that makes an investment can be either domestic investors or foreign investors. In the context of Investments Law, company that has a legal obligation to implement the CSR is not only the corporation but more broadly in terms of all corporate entities and individual company conducting investment business in Indonesia.

By referring the various definitions and concepts of CSR mentioned above, it can be considered that CSR is not philanthropy ${ }^{44}$ activities (charity) which is a charity per se, but rather an ongoing commitment and responsibility of a company together with other stakeholders (government, employees, NGOs or other social organizations, as well as local communities) to be responsible towards social issues, contribute to improving improve the quality of human / community and create a sustainable environment. Important element of CSR that distinguishes it from mere philanthropy is that CSR activities are always an ongoing responsibility. Meanwhile, in the activities of philanthropy if the company has donated a number of charitable aid in a social activity then the work is completed and the company has no further responsibility.

\section{The Corporate Legal Liability}

The corporate criminal liability approaches can be imposed as a last resort dealing with wrongful conduct of corporations. In the realm of European Union Law it seem that legal entities are fit subject of criminal law and can be held accountable for their wrongful conduct. The liability of legal entities is firmly established and accepted in European Union Law and in addition holding corporations accountable for wrongful conduct of their subsidiaries.

Corporate crime in practice is not only initiated by the corporate themselves but also on the other hand somehow related with State. Ronald C. Kramer referred to institutional collusion by public authorities as statecorporate crimes, solicitation by authorities to commit such illegal acts being the principal form. He distinguished of crime into state-initiated corporate crimes and state facilitated corporate crime. From the perspective of responsibility of superiors, the first category constituted a more serious offence than the second. For the first category, it was the authority which took the initiative and solicited illegal practice. The second type consisted of collusion patterns, in this matter the authorities served as facilitators and therefore acted as accessories. ${ }^{45}$ The business crime will emerge enormously when there are stimulus including state or authorities play important role. It has been showingvery dangerous phenomena.

${ }^{44}$ Philanthropy is the act of donating money, goods, time or effort to support a charitable cause, usually over an extended period of time and in regard to a defined objective.

${ }^{45}$ Grat van Den Heuvel, (2006). The parliamentary Enquiry on Fraud in the Dutch Construction Industry Collusion as concept between Corruption and State-Corporate Crime, Crime, Law \& Social change, 44: 140 . 
Corporate crime is defined as conduct of a corporation or of individuals acting on behalf of a corporation that is prescribed and punishable by law. Conventional crimes usually dealt with punitively, but corporate misbehavior was handled through administrative agencies or relatively lenient criminal status ${ }^{46}$. In general, the nature of business crime is:

1. Trade and commerce cannot operate without the element of trust

2. $\mathrm{BC}$ (what is BC?) starts with a violation of trustand ends with institutionalized illegal practices

3. Trade and commerce operate with risks. There are reasonable risks and unreasonable risks; there are lawful and unlawful risks

4. $\mathrm{BC}$ (What is BC) starts with unreasonable risks which run into unlawful risks

5. Trade and commerce operate with many informal rules, or self-regulated behavior schemes

6. BC starts with deviance within the context of the informal rules. So the first witnesses are colleagues and competitors.

Concerning corporate crime, John Braithwaite suggests that when the criminal justice system's failure to control corporation then radical approaches is needed in the hope that some of them might blossom into control strategies. Self regulation is one of a new strategy for corporate crime control. ${ }^{47}$ The misbehavior of corporations or even corporate crime is very close with collusion. Collusion is the secret agreement for a fraudulent or deceitful purpose, especially to defeat the course of law. Collusion may occur as result of secret agreement by private organization with private organization, governmental organization with governmental organ, and between governmental organizations with private organization. Crime is a variable of control. follows:

There are two models of organization control or control strategy as

\begin{tabular}{|c|l|l|}
\hline NO & \multicolumn{1}{|c|}{ COOPERATION MODEL } & \multicolumn{1}{|c|}{ CRIMINALIZATION MODEL } \\
\hline 1 & Compliance & Deterrence \\
\hline 2 & Pre-monitory & Post-monitory \\
\hline 3 & Prevention & Revenge \\
\hline 4 & Based on trust & Based on distrust \\
\hline 5 & Equal party model & Unequal party model \\
\hline 6 & $\begin{array}{l}\text { Measurement is felt as a failure of the } \\
\text { model }\end{array}$ & $\begin{array}{l}\text { Punishment is felt as a success of the } \\
\text { model }\end{array}$ \\
\hline 7 & Efficiency is high & Efficiency is low \\
\hline 8 & Democratic control dimension is low & Democratic control dimension is higher \\
\hline 9 & High collusion risk & Low collusion risk \\
\hline 10 & Low corruption risk & High corruption risk \\
\hline 11 & Distributive justice & Attributive justice \\
\hline Press. & $\begin{array}{l}46 \\
\text { Sally Simpson, (2002). Corporate Crime, Law }\end{array}$ and Social Control. UK: Cambridge University \\
\hline The Michigan Law Review Association. p.1466. & Regulation: A New Strategy for Corporate Crime Control. \\
\hline
\end{tabular}




\section{Conclusions}

Promoting sustainable tourism through human rights perspective is necessary for the benefit of all stakeholders (national, regional, international, and local administrations, enterprises, business associations, workers, local communities, tourists, non-governmental organization and bodies of all kinds belong to the tourist industries) for the present and the future generation. There are some legal instruments of the human rights such as the UDHR, the ICCPR, the ICESCR, and the African Charter on Human and Peoples Rights 1981 be utilized to promote sustainable tourism through human rights perspective. Despite the hard laws mentioned above, the UNWTO Global Codes of Ethics as existed in the form of the soft law provides non-legal binding instruments to promote human rights. To determine who has the duty to promote the rights to healthy environment is likely not only through the third generation human rights which falls under uncertainties but also very useful to observe from other existing treaty rights. The ICESCR, for example, can be utilized as a legal basis for the right to the clean environment that is associated with the right to life. Similarly, it is important to refer to the some human rights treaties including the soft law such as the UNWTO Global Codes of Ethics to determine who has the duty and responsibility when human rights violation have occurred in the context of the right to life, the right to work and the right to tourism in the tourism activities. The UNWTO Global Codes of Ethics clearly determines that all stakeholders have the duty; this is a soft law, however. By adopting this soft law into national law, the benefit of the UNWTO Global Codes of Ethics in promoting human rights can be regarded as legal binding instruments.

\section{Bibliography}

\section{Books}

Algan, Bulent. (2004). Rethinking "Third Generation" Human Rights, Ankara Law Review, Vol: 1 (Summer 2004)

Birnie, Patricia., Boyle, Alan., and Redgwell, Catherine. (2009). International Law \& the Environment, New York: Oxford University Press.

Burns, Peter M. \& Novelli, Marina. (2006). Tourism and Social Identities Global Frameworks and Local Realities. The Netherlands: Elsevier Ltd.

Engstrom,Viljam. (2002). Who is Responsible for Corporate Human Rights Violations? Abo Academy University Institute for Human Rights.

Fayed \& Fletcher. (2002). In Yvette Reisinger, (2009). International Tourism Cultures And Behavior. Oxford, UK: Butterworth-Heinemann.

Ghandhi. (2008). Blackstone's International Human Rights Documents $6^{\text {th }}$ Edition, Online Resource Centre, New York: Oxford University Press.

Heringa, Aalt Willem. (2006). Human Rights and General Principles and Their Importance as a Legislative Technique. Do they matter in legislation? An analysis with specific reference to environmental protection. In Michael Faure and Nicole Niessen. UK: Edward Elgar Publishing Limited.

Kamminga, T. \& Zia-Zarifi, Saman. (2000). Liability of Multinational Corporations under International Law. The Netherlands: Kluwer Law International. 
Kotler, Philip., \& Lee, Nancy. (2005). Corporate Social Responsibility, Doing the Most Good for Your Company and Your Cause. Canada: John Wiley \& Sons Inc.

Peeters, Marjan. (2006). Elaborating on integration of environmental legislation: the case of Indonesia. In Michael Faure and Nicole Niessen, (2006). Environmental Law in Development Lessons from the Indonesian Experience. UK: Edward Elgar Publishing Limited.

Sands, Philippe. (2003). Principles of International Environmental Law. UK: Cambridge University Press.

Smith, Mick. \& Duffy, Rosaleen. (2006). The Ethics of Tourism Development, New York : Routledge.

Simatupang, Violetta. (2009). Pengaturan Hukum Kepariwisataan Indonesia (The Legal Arrangement of Indonesian Tourism). Bandung, Indonesia: PT Alumni.

Susanto, A. B. (2009). Reputation-Driven Corporate Social Responsibility Pendekatan Strategic Management dalam CSR. Surabaya: Esensi, Erlangga.

Tomuschat, Christian. (2008). Human Rights Between Idealism and Realism. New York : Oxford University Press.

Widjaja, Gunawan. \& Pratama, Yeremia Ardi., (2008). Resiko Hukum \& Bisnis Perusahaan Tanpa CSR. Jakarta : Forum Sahabat.

\section{Digital Reference}

Central Department of Tourism \& Summer Resorts, available at www.discoveralex. com/GenerslDept_EN/Description,

Chatarayamontri, Nayamin. (2009). Sustainable Tourism And The Law: Coping With Clime Change, Dissertation \& Theses, Paper 6, available at http:// digitalcommons.pace.edu/lawdissertations

Elkington, John. (1997). Book reviews of Cannibals With Forks: the Triple Bottom Line of $21^{\text {st }}$ century Business, available at http://www.springerlink.com

George, Babu P., \& Varghese, Vinitha. (2007). Human Rights in Tourism: Conceptualization and Stakeholder Perspectives. EIBO Electronic Journal of Business Ethics and Organization Studies, Vol.12. No. 2, available at http://ejbo.jyu.fi/pdf/ejbo_vol12_no2_pages_40-48

Ruggie, John. (2011). UN Guiding Principles for Business \& Human Rights. Kennedy School of Government and Harvard Law School, available at http://lw.harvard.edu/corpgov/2011

Shah, Kishore., McHarry, Jan., \& Gardiner, Rosalie. (2002). Towards Earth Summit 2002, Sustainable Tourism-Turning The Tide, Briefing Paper, Economic Briefing No.4, p. 1, Stakeholder Forum-UNEP, United Nations Foundation, available at www.earthsummit 2002.org

Roach, Karen. "The International Year of Ecotourism: Tackling the Challenges of Global Regulation", Suffolk Transnational Law Review, 2011. p. 191 


\section{Regulations}

Universal Declaration of Human Rights (UDHR) proclaimed on United Nations General Assembly in Paris General Assembly resolution 217 A (III) on10 December 1948

International Covenant on Civil and Political Rights (ICCPR) adopted and opened for signature, ratification and accession by General Assembly resolution 2200A (XXI) of 16 December 1966

International Covenant on Economic, Social and Cultural Rights (ICESC). Adopted and opened for signature, ratification and accession by General Assembly resolution 2200A (XXI) of 16 December 1966

African Charter on Human and People's Rights ("Banjul Charter") proclaimed by Organization og African Unity on 27 June 1981

The Global Code of Ethics for Tourism (GCET) proclaimed as a resolution of the United Nations World Tourims Organization (UNWTO) General Assembly, meeting in Istanbul, Turkey, in 1997

Act No. 32, Year 2009 concerning Indonesian Act of Protection and Environmental Management.

Act No. 10, Year 2009 concerning Indonesia Act of Tourism.

\section{Cases}

European Court of Human Rights, 8 July 2003, Hatton and others v. United Kingdom (Hatton 2)

Fedeyeva v Russia (2005) European Convention on Human Rights 376

Guerra v Italy (1998) 26 European Human Right Reports 357

Lopez Ostra v Spain (1994) 20 European Human Right Reports 277 